\title{
Highly conserved sequences of three major virion proteins of a Korean isolate of white spot syndrome virus (WSSV)
}

\author{
Chang Hoon Moon ${ }^{1}$, Jeong Wan $\mathrm{Do}^{2}$, Seung Ju Cha ${ }^{2}$, Won Joon Yoon ${ }^{1}$, \\ Seong Bum Kim ${ }^{1}$, Myoung Seok Ko' ${ }^{1}$, Myoung Ae Park ${ }^{2}$, Jin Woo Kim², \\ Sang Kyu Sohn' ${ }^{2}$, Jong Hwa Lee ${ }^{3}$, Jeong Woo Park ${ }^{1, *}$ \\ ${ }^{1}$ Department of Biological Sciences, University of Ulsan, Ulsan 680-749, Korea \\ ${ }^{2}$ Pathology Division, National Fisheries Research \& Development Institute, Kijang, Pusan 626-900, Korea \\ ${ }^{3}$ Lee \& Joe Biotech Co., SoonChunHyang University Technology Business Incubator B307, Asan Choongnam 336-745, Korea
}

\begin{abstract}
In Korea, mass mortality occurred among cultured shrimp with visible macroscopic white spots in 2000, and we confirmed the presence of white spot syndrome virus (WSSV) in the tissues of moribund shrimp by electron microscopy. In order to identify the characteristics of this Korean isolate of WSSV, we cloned and characterized its genomic DNA coding for VP24, VP26, and VP28. On the nucleotide level, VP24, VP26, and VP28 of the Korean isolate were found to be $100 \%$, $100 \%$, and $99 \%$ identical to those of Taiwan, Thailand and Chinese isolates, respectively. On the deduced amino-acid level, all 3 virion proteins showed $100 \%$ identity to those of the foreign isolates. The extent of sequence identity suggests that the Korean isolate originated from the same ancestor as the Taiwanese, Thai and Chinese isolates.
\end{abstract}

KEY WORDS: White spot syndrome virus · Korean WSSV isolates · Conserved virion proteins Resale or republication not permitted without written consent of the publisher

\section{INTRODUCTION}

Since the early 1990s, white spot syndrome virus (WSSV) has caused catastrophic multimillion-dollar crop losses in shrimp farms across Asia, including Taiwan, Thailand, Japan, the Philippines and India (Chou et al. 1995, Mohan et al. 1998, Magbanua et al. 2000). This pathogen has rapidly spread to farmed and wild shrimp populations in the United States (Lightner 1996, Nadala \& Loh 1998) and Central and South America.

WSSV is an enveloped, ovoid virus with a rodshaped nucleocapsid with flat ends (Wang et al. 1995, Wongteerasupaya et al. 1995). Originally, WSSV was classified as an unassigned member of the Baculoviridae (Francki et al. 1991). However, recent sequence analyses of WSSV genes showed no relatedness to known baculovirus proteins. For example, ribonucleotide reductases (RR1 and RR2) (van Hulten et al. 2000b) and viral capsid proteins (VP26 and VP28) (van Hulten et al. 2000c) of WSSV showed no homology to known baculovirus proteins or to other proteins in databases. In addition, the entire nucleotide sequence of the WSSV genome revealed that many of the predicted proteins have no homology with other viral or cellular genes (van Hulten et al. 2001, Yang et al. 2001). Based on these results and the unusually wide host range of WSSV (Flegel 1997), it is proposed that WSSV might be a representative of a new virus family (van Hulten et al. 2000a).

Since 1993, epizootics have occurred among cultured shrimp in Korea. In 1998, Park et al. observed the presence of enveloped rod-shaped virus particles in the infected tissues by electron microscopy. The authors described the virus as having combined characters of WSSV and a rod-shaped nuclear virus of Penaeus japonicus (RV-PJ) (Inouye et al. 1994). These 2 viruses are now considered to be the same (Lightner 1996). In 2000 , mass mortality occurred among cultured shrimp in Korea, and we confirmed the presence of WSSV in the tissues of moribund shrimp by electron microscopy. In 
order to identify the characteristics of this Korean isolate of WSSV, the genes for 3 virion proteins, VP24, VP26, and VP28, were cloned and their sequences were compared with the available pool of WSSV gene sequences in the GenBank/EMBL databases. From these comparisons, we confirmed the occurrence of WSSV in Korea and deduced that the VP24, VP26, and VP28 genes are highly conserved among the Korean isolate and geographically different foreign isolates.

\section{MATERIALS AND METHODS}

Virus samples. The virus sample used in this study was obtained from moribund Penaeus chinensis shrimp cultured in Korea during epizootics in 2000. Infected tissue was homogenized in a TN buffer (20 mM Tris- $\mathrm{HCl}$ and $400 \mathrm{mM} \mathrm{NaCl}, \mathrm{pH}$ 7.4). After centrifugation at $1700 \times g$ for $10 \mathrm{~min}$, the supernatant was treated with proteinase $\mathrm{K}(0.2 \mathrm{mg} / \mathrm{ml})$ and sarcosyl $(1 \%)$ at $45^{\circ} \mathrm{C}$ for $3 \mathrm{~h}$, followed by phenol/chloroform extraction and ethyl alcohol precipitation. The genomic DNA in the pellet was dissolved in TE $(10 \mathrm{mM}$ Tris- $\mathrm{HCl}$ and $1 \mathrm{mM}$ EDTA, $\mathrm{pH}$ 7.5) and used as a template for PCR.

Electron microscopy. Infected tissues of shrimp were fixed with $2.5 \%$ glutaraldehyde in a phosphate buffer (pH 7.2) at $4^{\circ} \mathrm{C}$ for $4 \mathrm{~h}$, and post-fixed with $1 \%$ osmium tetroxide in a phosphate buffer ( $\mathrm{pH} 7.2)$ at room temperature for $2 \mathrm{~h}$. After post-fixation, cells were dehydrated in ethanol and embedded in Epon 812. Thin sections were cut with an ultramicrotome (LKB), stained with uranyl acetate and lead solution, and observed with a JEOL 1200 EX-2 electron microscope.

Polymerase chain reaction (PCR) of WSSV VP24, VP26, and VP28 genes. PCR was performed to amplify complete open reading frames (ORF) of 3 major virion proteins of WSSV, VP24, VP26, and VP28. Primers for PCR were designed from nucleotide sequences in the GenBank/EMBL databases of WSSV (AF228518 for VP24, AF173992 for VP26, and AF173993 for VP28). The PCR primers were as follows:

VP24 upstream: 5'-ATGCACATGTGGGGGG-TTTACGCC-3'

VP24 downstream: 5'-TTATTTTTCCCCAACCTTAAACAG-3'

VP26 upstream:

5'-ATGGAATTTGGCAACCTAACAAACC-3'

VP26 downstream:

5' -TTACTTCTTCTTGATTT-CGTCCTTG-3'

VP28 upstream:

5'-ATGGATCTTTCTTTC-ACTCTTTCGG-3'

VP28 downstream:

5'-TTACTCGGTCTCAGTGCCAGAGTAGG-3'
The template was genomic DNA from the infected tissues of Penaeus chinensis in Korea. The gene amplification reaction conditions were as follows: 1 cycle of $94^{\circ} \mathrm{C}$ for $5 \mathrm{~min} ; 35$ cycles of $92^{\circ} \mathrm{C}$ for $30 \mathrm{~s}, 60^{\circ} \mathrm{C}$ for $1 \mathrm{~min}$, and $72^{\circ} \mathrm{C}$ for $1 \mathrm{~min}$; and 1 cycle of $72^{\circ} \mathrm{C}$ for $5 \mathrm{~min}$. The amplified PCR products were cloned into a pGEM-T vector (Promega), and sequencing was performed at the Immunomodulation Research Center, Korea, on an automatic DNA sequencer (Applied Biosystems) according to the dye terminator procedure, with forward and reverse primers and overlapping primers designed from the sequencing results. The DNA and the deduced amino acid sequences were compared with the GenBank/EMBL databases using BLAST.

\section{RESULTS AND DISCUSSION}

During the epizootics in 2000, gross mortality occurred among cultured shrimp on the western Korean coast. The moribund shrimps displayed visible macroscopic white spots in the carapace at the time of sampling. Electron microscopy of the infected tissues revealed the presence of ovoid virus particles 240 to $280 \mathrm{~nm}$ in length and 60 to $80 \mathrm{~nm}$ in width. These results suggested that the causative agent was WSSV. In order to confirm this, the ORFs of 3 major virion proteins of WSSV, VP24, VP26, and VP28 were amplified by PCR and the products were analyzed by agarose gel electrophoresis. The sizes of the PCR products were almost the same as those expected from the database sequences (i.e. about 627 bp for VP24 and 615 bp for VP26 and VP28).

The PCR products were cloned into pGEM-T vectors and sequenced. From the nucleotide sequences, deduced amino acid sequences were obtained. The VP24 ORF (GenBank accession number AF380840) of our product was 627 bases long and coded for a protein of 208 amino acids with a calculated MW of $23.15 \mathrm{kDa}$. The VP26 ORF (AF380841) was 615 nt in length and coded for a protein of 204 amino acids with a calculated MW of $22.16 \mathrm{kDa}$. The VP28 ORF (AF380842) was 615 nt in length and coded for 204 amino acids with a calculated MW of $22.14 \mathrm{kDa}$. Blast analysis of these sequences revealed high similarity with those of WSSV virion protein genes in the GenBank/EMBL databases provided from Thailand (van Hulten et al. 2000a,c), China (Yang et al. 2001) and Taiwan. The nucleotide sequences of VP24 and VP26 of the Korean isolate were $100 \%$ identical to those from Taiwan, Thailand and China. In VP28, a C in the foreign isolates was replaced by $\mathrm{T}$ in the Korean isolate at Position 176 downstream of A (+) of the VP28 start codon. To rule out the possibility that this single nucleotide 
difference in the Korean isolate arose as an artifact during PCR amplification, 3 independently generated PCR products were sequenced and revealed the same $1 \mathrm{bp}$ replacement. However, this change did not result in any amino acid changes. Thus all of the VP24, VP26 and VP28 amino acid sequences of the Korean WSSV isolate had $100 \%$ identity with those of the Taiwanese, Thai and Chinese isolates of WSSV.

Analysis of the nucleotide sequences of the DNA encoding viral capsid proteins, VP24, VP26, and VP28 of WSSV enabled us to establish that the Korean isolate was conspecific with the other isolates of WSSV studied. Thus, the Korean isolate may have been introduced into Korean shrimp farms via imported shrimp. This confirms a previous observation that there is little genetic variation in geographic isolates of WSSV from China, India, Thailand, and the USA (Lo et al. 1999).

However, there are also reports that protein profiles (Wang et al. 2000) and restriction fragment length polymorphism (RFLP) (Nadala et al. 1998) were not identical for all the different geographical isolates. Moreover, analysis of the complete WSSV genome sequence suggests the possible presence of genetic heterogeneity (van Hulten et al. 2001). Therefore it may be too soon to conclude that all WSSV geographical isolates are genetically identical, and it is possible that different types of WSSV will eventually be found in different organisms or in different regions outside Asia.

Acknowledgements. This study was supported by a grant from Lee \& Joe Biotech Co.

\section{LITERATURE CITED}

Chou HY, Huang CY, Wang CH, Chiang HC, Lo CF (1995) Pathogenicity of a baculovirus infection causing white spot syndrome in cultured penaeid shrimp in Taiwan. Dis Aquat Org 23:165-173

Flegel TW (1997) Major viral diseases of the black tiger prawn (Penaeus monodon) in Thailand. World J Microbiol Biotechnol 13:433-442

Francki RIB, Fauquet CM, Knudson DL, Brown F (1991) Classification and nomenclature of viruses: fifth report of the International Committee on Taxonomy of Viruses. Springer-Verlag, New York

Inouye $\mathrm{K}$, Miwa $\mathrm{S}$, Oseko $\mathrm{N}$, Nakano $\mathrm{H}$, Kimura $\mathrm{T}$, Momoyama K, Hiraoka M (1994) Mass mortality of cultured

Editorial responsibility: Jo-Ann Leong,

Kaneohe, Hawaii, USA kuruma shrimp Penaeus japonicus in Japan in 1993: electron microscopic evidence of the causative virus. Fish Pathol 29:149-158

Lightner DV (1996) A handbook of shrimp pathological and diagnostic procedures for diseases of cultured penaeid shrimp. World Aquaculture Society, Baton Rouge, LA

Lo CF, Hsu HC, Tsai MF, Ho CH, Peng SE, Kou GH, Lightner DV (1999) Specific genomic DNA fragment analysis of different geographical clinical samples of shrimp white spot syndrome virus. Dis Aquat Org 35:175-185

Magbanua FO, Natividad KT, Migo VP, Alfafara CG and 6 others (2000) White spot syndrome virus (WSSV) in cultured Penaeus monodon in the Philippines. Dis Aquat Org 42:77-82

Mohan CV, Shankar KM, Kulkarni S, Sudha PM (1998) Histopathology of cultured shrimp showing gross signs of yellow head syndrome and white spot syndrome during 1994 Indian epizootics. Dis Aquat Org 34:9-12

Nadala ECB, Loh PC (1998) A comparative study of three different isolates of white spot virus. Dis Aquat Org 33: 231-234

Park JH, Lee YS, Lee S, Lee Y (1998) An infectious viral disease of penaeid shrimp newly found in Korea. Dis Aquat Org 34:71-75

van Hulten MC, Goldbach RW, Vlak JM (2000a) Three functionally diverged major structural proteins of white spot syndrome virus evolved by gene duplication. J Gen Virol 81:2525-2529

van Hulten MC, Tsai MF, Schipper CA, Lo CF, Kou GH, Vlak JM (2000b) Analysis of a genomic segment of white spot syndrome virus of shrimp containing ribonucleotide reductase genes and repeat regions. J Gen Virol 81: 307-316

van Hulten MC, Westernberg M, Goodall SD, Vlak JM (2000c) Identification of two major virion protein genes of white spot syndrome virus of shrimp. Virology 266: $227-236$

van Hulten MC, Witteveldt J, Peters S, Kloosterboer N and 5 others (2001) The white spot syndrome virus DNA genome sequence. Virology 286:7-22

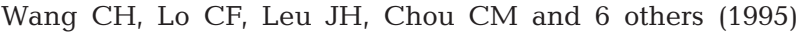
Purification and genomic analysis of baculovirus associated with white spot syndrome (WSBV) of Penaeus monodon. Dis Aquat Org 23:239-242.

Wang Q, Poulos BT, Lightner DV (2000) Protein analysis of geographic isolates of shrimp white spot syndrome virus. Arch Virol 145:263-274

Wongteerasupaya C, Vickers JE, Sriuraitatana S, Nash GL and 6 others (1995) A non-occluded, systemic baculovirus that occurs in cells of ectodermal and mesodermal origin and causes high mortality in the black tiger prawn Penaeus monodon. Dis Aquat Org 21:69-77

Yang F, He J, Lin X, Li Q, Pan D, Zhang X, Xu X (2001) Complete genome sequence of the shrimp white spot bacilliform virus. J Virol 75:11811-11820

Submitted: February 6, 2002; Accepted: September 26, 2002 Proofs received from author(s): December 16, 2002 